\title{
Światopoglądowe wyzwania bioetyki
}

Coraz powszechniejszym staje się przekonanie, że procesy modernizacji, których podstawowym generatorem jest nauka i technika, a w omawianych przez nas zagadnieniach biotechnologia, zderzają się z aksjologią (zwłaszcza religijną), stojącą na straży zasad moralnych. Zjawisko to jest szczególnie widoczne w przypadku tworzenia i rozwoju bioetyki kulturowej. ${ }^{1}$ Mamy tu bowiem do czynienia z możliwością istnienia, często sprzecznych ze sobą, stanowisk oraz interesów różnych odmian uprawiania bioetyki, jak również problemem zasadności stosowania języka i argumentów aksjologii do opisu zasad postępowania medycznego. Praktyka zaś dowodzi, iż wartościowanie nie da się wyeliminować ze sfery publicznej dyskusji na tematy zagadnień biomedycyny. Tym bardziej, że w niektórych (np. wyznaniowych) instytucjach naukowo- dydaktycznych powołuje się katedry bioetyki świadomie opierając ją na systemach wartości. ${ }^{2}$

Odwoływanie się bioetyki do przesłania aksjologicznego, mieszczącego się w tradycji intelektualnej Kościoła katolickiego oraz aktualizowanego każdorazowo w jego dokumentach bieżących, jest szczególnie widoczne w Polsce. Punktem wyjścia rozważań bioetycznych światopoglądowej opcji katolickiej jest niepowtarzalna zasada „świętości życia, będąca podstawą aksjologiczną dla wyprowadzanych z niej praktycznych reguł postępowania. Propagowaniu idei absolutnej godności osobowej człowieka ma służyć specjalnie do tego celu powołana przez Jana Pawła II w 1994 r. Papieska Akademia Zycia, której konkretne działania kreśli encyklika „Evangelium vitae”. ${ }^{3}$ Należy zaznaczyć, iż współczesne wyzwania bioetyki wobec sfery zasad moralnych nie są czymś w historii kultury europejskiej. Znane są bowiem przypadki, kiedy przekonania światopoglądu religijnego i sfera moralności zderzały się z takimi czy innymi poczynaniami decydentów „zagospodarowujących" myśli uczonych i filozofów.

Por. K. Szewczyk, Dobro, zło i medycyna. Filozoficzne podstawy bioetyki kulturowej, WarszawaŁódź 2001.

2 R. ОтоWICz SJ, Etyka życia. Bioetyczny i teologiczny kontekst problematyki życia poczętego, Kraków 1998.

3 Przykładami prac z dziedziny bioetyki katolickiej są: T. StIPko, Granice życia. Dylematy wspótczesnej bioetyki, Kraków 1994; B. CHYrowicz SSpB, Bioetyka i ryzyko. Argument „równi pochyŁej" w dyskusji wokót osiagnięć wspótczesnej bioetyki, Lublin 2000. 
Jednakże szczególną postacią wyzwania dla światopoglądu humanistycznego, a religijnego w szczególności, jest współczesna bioetyka, a jeszcze bardziej szybki postęp biomedyczny. Sytuacja ta rodzi konieczność pogłębionej refleksji nad miejscem moralności i teologii we współczesnych poszukiwaniach bioetycznych, ${ }^{4}$ szczególnie gdy idzie o trzy podstawowe dziedziny zainteresowań bioetyki:

- techniki biomedyczne stosowane u początków życia ludzkiego (sztuczna prokreacja, diagnostyka prenatalna, manipulacja genetyczna, eugenika i aborcja);

- technik biomedycznych stosowanych u kresu życia ludzkiego (eutanazja, opieka paliatywna, pobieranie organów od umierających, przedłużenie życia);

- eksperymentów medycznych na ludzkim ciele (dysponowanie ludzkim ciałem, przeszczepy organów itp.).

Należy więc przyjrzeć się wymienionym dziedzinom pod kątem kreowanych przez nie problemów światopoglądowych i etycznych.

\section{Bioetyka a teologia}

W świetle założeń i prawd teologii katolickiej współczesna bioetyka przechodzi kryzys. Jest on w dużej mierze spowodowany tym, że zagadnienia przed nią stojące zdają się ją przerastać. ${ }^{5}$ Składa się na to zarówno złożony charakter samego przedmiotu refleksji bioetycznej, jak też szeroki wachlarz uwarunkowań: społeczno- politycznych, ideologicznych i filozoficznych. W konsekwencji pojawiają się więc opinie, według których tego rodzaju sytuacja wymaga oparcia refleksji bioetycznej na fundamencie takiej antropologii filozoficznej, która pozwoliłaby bioetyce regulować ludzkie działania i umożliwiłaby odpowiedzialne dysponowanie biologicznymi podstawami ludzkiego życia. ${ }^{6} \mathrm{Z}$ tym zaś wiąże się pytanie, $w$ jakim stopniu i jakie postawy moralne jest w stanie kreować współczesna bioetyka? Pytanie to wydaje się o tyle zasadne, że pomiędzy postulatami bioetyki a praktycznym wcielaniem ich w życie obserwuje się narastający rozziew. Niektórzy etycy sądzą, że jego źródeł należy się doszukiwać w relatywizmie i subiektywizmie tzw. świeckiej bioetyki. ${ }^{7}$ Opinia ta skłania więc teologów i moralistów o teistycznej orientacji światopoglądowej do twierdzenia, iż warunkiem prawidłowego rozwoju bioetyki jest potrzeba określenia jej pryncypiów, z któ-

\footnotetext{
4 Sporą wiedzę na temat zadań teologów wobec wyzwań bioetyki przynoszą opracowania: Theology and Bioethics. Exploring the Foundations and Frontiers, red. E.E. Shelp, Dordracht 1985; Bp E. SGRECCIA, Człowiek wobec wyzwań nauk biomedycznych, w: Medycyna i prawo: za i przeciw życiu?, red. Bp E. Sgreccia, T. Styczeń i inni, Lublin 1999.

5 Por. St.Warzeszak, Teologia wobec wyzwań bioetyki, „Warszawskie Studia Teologiczne” 1994, t. VII, s. 175.

6 Tamże.

7 Z. ChŁaP, Problemy bioetyczne wspólczesnej Europy, „Studia Gdańskie” 1995, t. X, s. 68.
} 
rych podstawowym winien być personalizm prudencjalny przy podejmowaniu decyzji moralnej. Domaga się on uwzględnienia następujących warunków:

- należy postępować według podstawowego zobowiązania względem Boga i autentycznej godności osoby ludzkiej;

- w realizacji tego podstawowego zobowiązania należy wykluczyć to wszystko, co jest $\mathrm{z}$ nim sprzeczne;

- należy dokładnie ocenić szanse realizacji tego zobowiązania oraz wynikające $\mathrm{z}$ niego konsekwencje;

- należy wybrać najskuteczniejsze środki jego realizacji. ${ }^{8}$

Są to zarazem cztery etapy formułowania sądu prudencjalnego, wyartykułowanego przez teologię moralną pod adresem bioetyki. Znaczenie powyższych wskazań oraz ich rangę z punktu widzenia teologii chrześcijańskiej, jak też ukazanie miejsca wiary religijnej na gruncie bioetyki zawiera następująca wypowiedź: "Teolog katolicki przyjmuje, że wiara przenika poznanie człowieka we wszystkich jego wymiarach. $Z$ drugiej strony przyznaje, że imperatywy konkretnego działania moralnego są dostępne dla rozumu ludzkiego i nie muszą wynikać z magisterium wiary. Również na terenie bioetyki, wiara nie musi angażować się bezpośrednio w rozwiązywanie problemów, lecz rozum praktyczny kształtowany /informowany/ przez wiarę. Wiara nie dostarcza nam konkretnych odpowiedzi na problemy biomedyczne, tak jak nie stanowi bezpośredniego kryterium dla konkretnych sądów moralnych, jednakże ma ona wpływ na moralność w zakresie jej podstawowych odniesień. Na gruncie wiary można odkryć teologiczny i etyczny wymiar całokształtu fundamentalnych problemów związanych z działaniem człowieka w zakresie opanowywania biologicznych podstaw życia. Wiara i rozum przenikają się wzajemnie, i w ten sposób dostarczają pełniejszego poznania świata i człowieka, a także pozwalają odkryć właściwy sens oraz ustalić odpowiednią hierarchię wartości"’’

\section{Dylematy moralne bioetyki}

Spośród wielu zagadnień kontrowersyjnych na gruncie bioetyki interesuje nas zwłaszcza problematyka życia i sposób podejścia do niej Kościoła katolickiego. Znalazła ona odbicie w „Katechizmie Kościoła katolickiego”, jak również encyklikach kolejnych papieży, poczynając od Jana XXIII. „Katechizm” sprowadza omawiany problem do życia ludzkiego i rozpatruje go w kontekście szerszym, a mianowicie programu „nowej ewangelizacji”, czyniąc antropologiczno- perso-

\footnotetext{
Tamże.

9 St. WARZESZAK, dz.cyt., s. 180.
} 
nalistyczne ujęcie godności osoby ludzkiej podstawą dla refleksji nad sferą ludzkiego biosu.

Na czoło zagadnień „Katechizm” wysuwa problematykę ochrony życia, ujmując ją w następujące grupy tematyczne:

- poszanowanie życia ludzkiego

- poszanowanie godności człowieka

- ochrona kraju

Nas interesuje katechizmowa dyrektywa poszanowania ludzkiego życia. Zagadnienie to mieści w sobie takie kwestie szczegółowe, jak: legalna obrona osób i społeczności przed agresorem (nr 225...-2267), zabójstwo zamierzone (nr 2265-2269), aborcja (nr 2270-2276), eutanazja (nr 2276-2279) i samobójstwo (nr 2280-2283).

Gdy chodzi o legalną obronę osób i społeczności omawiany dokument kościelny dopuszcza możliwość użycia siły wobec agresora w celu obrony prawa do życia i dobra wspólnego: „Uprawniona obrona może być nie tylko prawna, ale poważnym obowiązkiem tego, kto jest odpowiedzialny za życie drugiej osoby, za wspólne dobro rodziny lub państwa" (nr 2265). W przypadku zabójstwa zamierzonego „Katechizm” zdecydowanie potępia tego rodzaju czyn, powołując się na piąte przykazanie Dekalogu. Zakazuje ono „pod grzechem ciężkim zabójstwa bezpośredniego i zamierzonego (...). Dzieciobójstwo, bratobójstwo, zabójstwo rodziców i zabójstwo współmałżonka są szczególnie ciężkimi przestępstwami z powodu naruszenia więzi naturalnych. Względy eugeniczne lub higiena społeczna nie mogą usprawiedliwić żadnego zabójstwa, choćby było nakazane przez władze publiczne" (nr 2268).

Szczególnie dużo miejsca poświęcają autorzy „Katechizmu” problematyce aborcji. Kościół katolicki stoi na stanowisku, że wszelka aborcja jest złamaniem piątego przykazania, czyli jest tożsama z zabójstwem, gdyż z chwilą poczęcia mamy do czynienia z osobą ludzką obdarzoną nieśmiertelną duszą. Pogląd ten wyartykułował papież Paweł VI w formie koncepcji "prawa do życia" w swej encyklice „Humanae vitae” (1978). Stwierdza ono, że troska o życie ludzkie wymaga zakazu aborcji. Powołując się na chrześcijańską naukę o małżeństwie Paweł VI pisal: „(...) należy bezwarunkowo odrzucić - jako moralnie niedopuszczalny sposób ograniczania ilości potomstwa - bezpośrednie naruszenie rozpoczętego już procesu życia, a zwłaszcza bezpośrednie przerwanie ciąży, choćby dokonywane ze względów leczniczych". ${ }^{10}$

Zagadnienie aborcji było też przedmiotem rozważ w opublikowanej wcześniej przez Kongregację Nauki Wiary „Deklaracji o przerywaniu ciąży” (1974). Dokument ten zawiera nie tylko wykład nauczania chrześcijańskiego w kwestii życia, ale ponadto zamieszcza odpowiedzi Magisterium Kościoła na zarzuty kie-

10 Encykliki (Jan XXIII, Paweł VI, Jan Paweł II), Warszawa 1981, s. 149. 
rowane pod jego adresem i postulaty liberalizacji kościelnego stanowiska w sprawie aborcji. Ząada się - czytamy w „Deklaracji” - "pluralizmu ideologicznego». Tymczasem chodzi o rzeczy, które bardzo się różnią między sobą. Działania bowiem dosięgają dobra innych niż czyste opinie. Nikomu przy tym pod żadnym pozorem nie wolno powoływać się na wolność opinii, gdy zostaną naruszone prawa drugich, zwłaszcza prawo do życia". ${ }^{11}$

Sprzeciw Kościoła katolickiego wobec aborcji przybrał na sile za pontyfikatu Jana Pawła II. Wszystkie wypowiedzi tego papieża ${ }^{12}$ jednoznacznie potępiają aborcję jako zabójstwo. Jan Paweł II deklaruje swoją determinację obrony życia ludzkiego, kiedy będzie ono zagrożone, kiedy atakowana będzie „świętość życia przed narodzeniem". W każdym z tych przypadków - nauczał Jan Paweł II - „będziemy się temu sprzeciwiać i głosić, że nikt nie ma władzy niszczenia nienarodzonego życia." ${ }^{13}$ Według Jana Pawła II współczesny człowiek żyje w lęku i obawach o własne życie, choć czyni się go „panem stworzeń”. Lęki i obawy biorą się stąd, że władza człowieka nad światem obraca się przeciwko niemu. Jedną z przyczyn tego stanu rzeczy jest irracjonalny sposób użytkowania Ziemi: „Człowiek zdaje się często nie dostrzegać innych znaczeń swego naturalnego środowiska, jak tylko te, które służą celom doraźnego użycia i zużycia. Tymczasem Stwórca chciał, aby człowiek obcował z przyrodą jako jej rozumny i szlachetny $<<$ pan $>>\mathrm{i}<<$ stróż $>>$, a nie jako bezwzględny „eksploatator”. „Kultura śmierci”- jak ją nazywa papież- ma więc swe źródło m.in. w rozbracie człowieka ze światem przyrody. Zdaniem Jana Pawła II „kultura śmierci” opiera się na trzech elementach składowych „racjonalizmu techniczno- naukowego”, który redukuje rzeczywistość do rzeczy, czlowieka natomiast uważa się za swoją wyłączną własność, „poddająca się bez reszty jego panowaniu i wszelkim manipulacjom” („Evangelium vitae”, 1995, nr 31).

Jedną z takich właśnie manipulacji jest ABORCJA. Stanowi ona zamach na życie u jego początku. U jego końca taką manipulacją jest eutanazja.

Pojęcie eutanazji wiąże się ściśle z tzw. zagadnieniami ostatecznymi, które od dawna stanowiły przedmiot namysłu filozofów i teologów, o czym zaświadcza wielowiekowa tradycja tanatologii (refleksji, mającej za przedmiot zagadkę śmier-

11 Dokumenty. Służba życiu podstawowym zadaniem rodziny, „Vox Patrum” 1985, z. 8-9; T. SIKonski, Questio de abortu precurata (Analiza tekstu), „Ateneum Kapłańskie” 1973, z. 3, s. 374-387.

12 Por. np. Instrukcja o szacunku dla rodzącego się życia ludzkiego i o godności jego przekazywania. Odpowiedzi na niektóre aktualne zagadnienie, Watykan 1987; F. MARciniec, Argumentacja współczesnego Kościoła na rzecz człowieczeństwa nienarodzonych, „Studia Theologica Varsaviensia" 1993, z. 2.

13 Homilia podczas Mszy św. Na Capitol Mall w Waszyngtonie, w: Jan Paweł II o małżeństwie i rodzinie, Warszawa 1983, s. 123. 
ci) oraz eschatologii (teologicznej wiedzy o życiu pozagrobowym).$^{14}$ Problem umierania i śmierci stał się przedmiotem rozważań bioetyki z chwilą, kiedy stała się ona dyscypliną samodzielną. Dokonało się to zaś pod wpływem postępu nauk medycznych, farmakologii i techniki. W efekcie pojawiło się również zainteresowanie problematyką starości, a geriatria stała się ważną dziedziną medycyny.

W obszarze problemowym tzw. zagadnień ostatecznych na uwagę zasługują zwłaszcza takie problemy, jak: ból i cierpienie, opieka nad umierającym, kara śmierci i śmierć embrionów. Wszystkie te zagadnienia wzbudzają kontrowersje na gruncie bioetyki i w codziennej praktyce życiowej, gdy chodzi o moralną ich kwalifikację. Szczególną kontrowersyjność wywołuje zagadnienie eutanazji.

Terminem tym zwykło się określać śmierć zadaną komuś z litości („dobra śmierć"). W dyskusjach nad tym zagadnieniem ujawniają się najczęściej opinie skrajnie przeciwstawne: zwolenników eutanazji i jej przeciwników. W tej sytuacji są głosy postulujące, aby w konkretnych sytuacjach i przypadkach decyzję o eutanazji pozostawić samemu choremu (gdy jest jeszcze przytomny), nie uciekając się do światopoglądowo-prawnych regulacji odgórnych. Rzecz jasna stanowiska zajęte w tej kwestii zależne są w pierwszej kolejności od deklarowanego światopoglądu i określonej przezeń hierarchii wartości.

Nic też dziwnego, że opinie na temat eutanazji są podzielone nawet wśród części ludzi wierzących - stwierdza ks. prof. Marian Rusecki, korespondent Pontificio Academia Theologica w Watykanie, na łamach miesięcznika Wyższej Szkoły Społeczno-Ekonomicznej „Oświata i Wychowanie”. M.Rusecki optuje rzecz jasna za stanowiskiem oficjalnego Kościoła. Stąd też wyrażając zrozumienie dla cierpień ludzi dotkniętych nieuleczalną chorobą, autor ten opowiada się za niedopuszczalnością zarówno eutanazji, jak też wszelkiego, czynnego bądź biernego pomocnictwa w dokonaniu tego czynu przez człowieka, szukającego w śmierci ucieczki przed bólem i brakiem jakichkolwiek szans na odzyskanie zdrowia. Chociaż - zastrzega się M.Rusecki - jeden z rodzajów eutanazji, eutanazja bierna, jest zagadnieniem bardziej zniuansowanym. „Gdy leczenie chorego nie rokuje żadnych nadziei- pisze Rusecki - można zaprzestać działań nadzwyczajnych, zwykle bardzo kosztownych. Powinno się jednak kontynuować terapię zwykłą i od niej nie należy odstępować. Zapewnia to bowiem prawo do godnego umierania". ${ }^{15}$

Odmienne stanowisko w kwestii eutanazji zajmują rzecznicy światopoglądu religijnego, które wyraża opinia Marii Szyszkowskiej. Neguje ona sposób insty-

14 Por. A. Toynbee i inni, Czlowiek wobec śmierci, PIW, Warszawa 1992; Antropologia śmierci. Myśl francuska, PWN, Warszawa 1993; L.Pearson (red.), Smierć i umieranie. Postępowanie z czlowiekiem umierającym, PZWL, Warszawa 1972.

15 Cyt. za: K. Żygulski, Trudne do rozstrzygnięcia dylematy, „Oświata i wychowanie” 2005, nr 7 (październik) 
tucjonalnego regulowania tej kwestii, a tym bardziej narzucanie całemu społeczeństwu rozwiązań dyktowanych przez jedną z wielu opcji światopoglądowych. M.Szyszkowska twierdzi więc, że „prawo nie powinno być wyrazem poglądów nawet najliczniejszej grupy religijnej. Zwraca się więc $\mathrm{z}$ apelem, aby pozwolić „żyć swobodnie w Polsce osobom bezwyznaniowym, agnostykom, ateistom oraz wyznawcom rozmaitych religii niechrześcijańskich. Prawne zezwolenie na eutanazję przyniesie tym, wymienionym wyżej grupom polskich obywateli wolność dokonywania wyboru i rozporządzania własnym życiem" ${ }^{16}$ Podsumowując toczącą się przez rok dyskusję na łamach wspomnianego miesięcznika „Oświata i Wychowanie”, Kazimierz Żygulski zwraca uwagę, ze wiele kontrowersji w takich kwestiach jak eutanazja wynika po części z niedość precyzyjnego zdefiniowania podstawowych pojęć. Dlatego też proponuje od siebie następujące określenie eutanazji: eutanazja oznacza „działanie (w tym i zaniechanie działania) mające spowodować śmierć proszącego o nią chorego, dotkniętego znaczącym, silnym i długotrwałym cierpieniem, wynikłym z choroby lub kalectwa, nie dających żadnych szans na wyleczenie". Autor ten podkreśla równocześnie, że nawet uściślenie pojęcia eutanazji nie może prowadzić do całkowitego ujednolicenia stanowisk. Rozbieżność opinii pozostanie, gdyż wynikają one z odmienności przesłanek światopoglądowych i hierarchii wartości. Chodzi więc nie tyle o jednomyślność, ile o humanistyczny klimat refleksji, stawiającej na pierwszym miejscu „wzajemny szacunek i dobro człowieka dotkniętego autentycznym, nieodwracalnym nieszczęściem" ${ }^{17} \mathrm{~W}$ takim klimacie łatwiej także o wypracowanie prawnej wykładni zagadnienia eutanazji.

Doktryna moralna Kościoła katolickiego uważa aborcję i eutanazję dlatego za zbrodnicze, ponieważ są one zaprzeczeniem personalistycznej zasady afirmacji człowieka jako osoby, jak również odrzuceniem postulatu miłości i troski o drugiego człowieka.

Doniosłym i zarazem kontrowersyjnym zagadnieniom aborcji i eutanazji Jan Paweł II poświęcił wiele miejsca w takich dokumentach, jak: adhortacja apostolska „Familiaris consortio” (1981), „List do rodzin” (1994), encyklika „Centesimus annus" (1991). W dokumentach tych można odnaleźć myśl, że niszcząc życie podważa się fundamenty ludzkiej cywilizacji i współistnienia jednostek i narodów. Zamach na ludzkie życie prowadzić musi do rozejścia się prawa i moralności. A przecież, argumentuje Jan Paweł II, integralność tych dwóch dziedzin jest podstawą dla afirmacji zycia i konieczności jego obrony. ${ }^{18}$

\footnotetext{
Tamże.

7 Tamże.

18 Por. M. Ozorowski, Życie jako wartośc, w: „Evangelium vitae” Jana Pawła II, „Studia Teologiczne", Białystok, Drohiczyn, Łomża 1999, nr 17, s. 55-65.
} 
W miarę jak aborcja i eutanazja przedstawiane są jako prawa, wzrasta zagrożenie egzystencji człowieka, dokonuje się „, tragiczny w skutkach zwrot w długim procesie historycznym, który doprowadziwszy do odkrycia idei «praw człowieka» - jako wrodzonych praw każdej osoby, uprzednich wobec konstytucji i prawodawstwa jakiegokolwiek państwa - popada dziś w zaskakującą sprzeczność; właśnie w epoce, w której uroczyście deklaruje się wartość życia, samo prawo do życia jest w praktyce łamane i deptane, zwłaszcza w najbardziej znaczących dla człowieka momentach istnienia, jakimi są narodziny i śmierć". ${ }^{19}$

Uwaga Jana Pawła II kieruje się również w stronę innego ważnego zagadnienia współczesnej bioetyki, jakim są eksperymenty medyczne. Najpełniej swoje stanowisko w tej kwestii wyraża papież w encyklice „Veritatis splendor”. ${ }^{20}$ Szczególnie podrozdział pierwszy rozdziału drugiego tego dokumentu wiele miejsca poświęca rozważaniom nad relacjami pomiędzy wolnością i prawem. Jan Paweł II zauważa tam, iż rzekomy konflikt między prawem i wolnością jest źródłem problemów w etycznej ocenie działań biomedycznych, które zawierają się pomiędzy tym, co człowiek może uczynić (wolność), a tym, co musi wykonać (prawo). ${ }^{21}$

Rejestr zagadnień odnoszących się do moralnych aspektów eksperymentów medycznych obejmuje także rozważania Jana Pawła II na temat inżynierii genetycznej. We wspomnianej encyklice „Veritatis splendor" papież stwierdza, że tworzenie wartości ekonomicznych, społecznych, kulturowych i moralnych, gdyby miało się dokonywać w drodze nieograniczonego rozszerzania władzy człowieka, a więc jego wolności- doprowadziłoby do pozbawienia go własnej natury. Oznaczałoby to kształtowanie siebie ,jedynie według własnego projektu". Człowiek nie byłby zatem niczym innym, jak tylko „własną wolnością". ${ }^{22} \mathrm{Ta}$ natomiast znajduje praktyczny wymiar w rozwoju genetyki oraz inżynierii genetycznej. Nie kryjąc obaw przed negatywnymi skutkami rozwoju technik inżynierii genetycznej Jan Paweł II podkreśla, że człowiek nie może poprawiać natury w sposób dowolny, lecz winien kierować się odwiecznym prawem Bożym, którym „Stwórca wedle planu mądrości i miłości swojej, porządkuje, kieruje i rządzi całym światem i losem wspólnoty ludzkiej".23

\footnotetext{
19 J. Ratzinger, Problem zagrożén życia ludzkiego, „Osservatore Romano” 1991, nr 7, s. 7. Por. także: Kongregacja Nauki Wiary, Deklaracja o eutanazji „Iura et bona” (5.V.1980), 2: Acta Apostolicae Sedis 1980, $\mathrm{nr} 72$, s. 546-551.

20 JAN PAWE⿺ II, Encyklika „Veritatis splendor”, Poznań 1993.

21 Por. J. BRusiŁo, Niektóre problemy bioetyki na tle encykliki „Veritatis splendor”, „W nurcie franciszkańskim" 1995, z. 4, s. 87.

22 ,Veritatis splendor", $\mathrm{nr} 46$.

23 Tamże, nr 45.
} 
Problematyka życia ludzkiego ma w rozważaniach Jana Pawła II szerszy wymiar, aniżeli tylko odnoszący się do jednostkowej i społecznej egzystencji homo sapiens. Obejmuje ona bowiem szerokie spektrum problemów bioetycznych, poddanych głębokim analizom pod kątem zagrożeń podstaw istnienia życia na Ziemi. To sprawia, że różnice światopoglądowe nie mogą wpływać na współdziałanie wszystkich ludzi w obronie podstawowych praw czlowieka, na czele z jego prawem do godnego życia.

\section{Potrzeba etyki odpowiedzialności}

Współczesna epoka stoi pod znakiem odpowiedzialności. Wzrasta ranga odpowiedzialności i jej wartość jako przysługującej człowiekowi własności postępowania. Na tak wysoką pozycję odpowiedzialności za całokształt działań człowieka w obrębie biosfery składa się w pierwszej kolejności niebywały stopień organizacji i dynamiki przemian cywilizacyjnych i kulturowych. Jak zauważa Mieczysław Michalik, zasada odpowiedzialności „staje się w tych warunkach jednym z podstawowych wymagań społeczno- moralnych" ${ }^{24} \mathrm{~W}$ duchu H.Jonas opowiada się za potrzebą całkiem nowej etyki, otwierającej „nowy wymiar etycznej ważności, dla której wśród wzorów i kanonów etyki tradycyjnej nie ma precedensu”. 25

Zarysowany model etyki odpowiedzialności ma wymiar globalny: obejmuje swym zasięgiem zarówno sferę relacji interpersonalnych jak też ogólnoludzkich. Podstawą tej etyki ma być, według wspomnianego H.Jonasa, imperatyw, któremu autor ten daje następujące brzmienie: „Postępuj tylko w taki sposób, aby skutki twego działania dały się pogodzić z ciągłością trwania autentycznego życia ludzkiego". Adresatem tego paradygmatu mają być „nie tyle indywidualne osoby, co przede wszystkim establishmenty polityczne, militarne, gospodarcze różnych państw świata, a w szczególności tych najbogatszych i najpotężniejszych". ${ }^{26}$

Świadomość odpowiedzialności etycznej w dziedzinie nauki i techniki, sposobów wykorzystywania ich zdobyczy, narzuca potrzebę sformułowania i akceptacji nowych dyrektyw zachowań, u których podstaw leżałoby poczucie współodpowiedzialności również każdej jednostki ludzkiej za ekosferę, za kształt bezpośrednich kontaktów międzyludzkich, za czyny przynoszące cierpienia wyrządzone sobie i innym. Chodzi więc o nowy kształt etyki - etyki o zasięgu globalnym, budowanej na miarę wielkości i ważkości aktualnych i przyszłych wyzwań. Potrzeba takiej etyki wynika również z odczuwanej potrzeby „pewnego minimum wspólnych wartości, moralnych atrybutów i moralnych standardów”.

\footnotetext{
${ }^{24}$ M. Michalik, Etyka odpowiedzialności - wyzwaniem wspólczesności, w: Bezpieczeństwo i wolność jako kategorie kulturowe i społeczne, pr. zb., red. J. Dębowski, Siedlce 2004, s. 65.

${ }_{25}$ H. Jonas, Zasada odpowiedzialności, Kraków 1996, s. 22.

26 Tamże.
} 
Autor tych słów - Hans Kung - zwraca uwagę, iż ta nowa etyka globalna nie jest zaprzeczeniem „Kazania na Górze” i nie dąży ona także do eliminacji Tory lub Koranu. Próbuje ona jedynie odnaleźć to, co jest wspólne tym wielkim tradycjom i religiom. H.Kung idzie dalej w swych wywodach i twierdzi, że niemożliwy jest nowy porządek światowy bez nowego światowego etosu, bez wypracowania wspólnej dla wszystkich narodów wizji przyszłości, tym samym powstanie ludzkiej wspólnoty „w akceptowaniu określonych wartości, miar i celów”. ${ }^{27}$

Tak więc jesteśmy świadkami narodzin nowej etyki, określającej kierunek i kształt poszukiwań takich sposobów wykorzystywania wytworów ludzkiej działalności w dziedzinie nauki i techniki, które nie będą kolidowały z fundamentalnymi prawami człowieka i natury. Jest to wyzwanie stojące przed ludzkością. Sprostanie temu wyzwaniu stworzy możliwość rozwiązywania nowych problemów moralnych, generowanych przez cywilizacyjne trendy naszych i przyszłych czasów.

\title{
World viewed challanges of bioethics
}

\author{
SUMMARY
}

The article includes detailed analysis of basic relations between bioethics and other sciences. The author shows relation between bioethics and theology, he presents basic moral dilemmas of bioethical researches and elementary justification of the need of responsibility ethics.

7 H. Kung, Future Generations Journal, 1995, s. 1. Cyt. za: H. Skolimowski, Od Etyki Nikomachejskiej do etyki globalnej, w: Idea etyczności globalnej, pr.zb., red. J.Sekuła, wyd. I, Siedlce 1999, s. 28. Por. tegoż: Pokój na świecie - światowe religie - światowy etos, tłum. M.Filipiak, w: „Idea etyczności globalnej”, wyd.cyt., s. 35. 